\title{
Stingless Bee Honey as Bio-Indicator of Heavy Metals Pollution in and around the University of Ilorin Environ Kwara State, Nigeria
}

\author{
${ }^{1 *}$ OKEOLA, FO; ${ }^{1}$ OLUADE, O; ${ }^{2}$ LIAD, MT \\ ${ }^{l}$ Department of Industrial Chemistry, Faculty of Science, ${ }^{2}$ Department of Forestry, Faculty of Agriculture, University of Ilorin, Ilorin, \\ Nigeria. \\ *Corresponding Author.Email: Okeolaf@yahoo.com; Okeola.of@unilorin.edu.ng
}

\begin{abstract}
Honey from stingless bees was examined as an indicator to evaluate the level of heavy metal pollution at six sampling locations (Oyun A, Oyun B, Bolounduro A, Bolounduro B, Jalala and Quarters) in and around University of Ilorin. Using the dry ashing digestion method the concentration of metals $(\mathrm{Pb}, \mathrm{Cr}, \mathrm{Cd}, \mathrm{Cu}, \mathrm{Zn})$ were analyzed using Atomic Absorption Spectrometer. The concentration of metal $(\mu \mathrm{g} / \mathrm{kg})$ in the honey samples ranged from 0.010-0.001 for $\mathrm{Cd}, 3992.33-1755.67$ for $\mathrm{Zn}, 2319.33-592.33$ for $\mathrm{Cu}, 29.67$ - 4.33 for $\mathrm{Cr}$ while $\mathrm{Pb}$ with concentration of $1 \mu \mathrm{g} / \mathrm{kg}$ was found in only Quarter sample. $\mathrm{Zn}$ was the most abundant metal detectable in all the samples with the highest and least concentration obtainable from Oyun B and Bolounduro B respectively. Statistical analysis of the studied metals showed $\mathrm{Cu}$ and $\mathrm{Zn}$ differ significantly out of the five studied metals. The highest concentration of $\mathrm{Cu}$ was observed in Oyun A sample the least was found in the Bolounduro A. Highest concentration for $\mathrm{Cr}$ was found in Oyun B while the least was obtained in Oyun A sample. Cd presented the lowest concentration level in all tested samples.All the detected heavy metals in the honey samples were at concentrations within their respective WHO permissible limit.Physicochemical Parameters like density, moisture content, free acidity, $\mathrm{pH}$, ash content and electrical conductivity of the honey samples were also predetermined. The mean density of the honeys is $1.44 \pm 0.02$, moisture content $14.25 \pm 2.52$, $\mathrm{pH} 4.61 \pm 0.25$, free acidity $44.08 \pm 2.46$, Ash $1.48 \pm 0.64$ and electrical conductivity $0.04 \pm 0.03$. There was significant difference noted between the studied physicochemical parameters and strong correlations observed among some of the studied parameters. Some of the positive and negative detection of the result were found to correlate with activity and suspected pollutant in some of these sampling locations.
\end{abstract}

DOI: $\underline{\text { https://dx.doi.org/10.4314/jasem.v24i5.7 }}$

Copyright: Copyright (C) 2020 Okeolaet al. This is an open access article distributed under the Creative Commons Attribution License (CCL), which permits unrestricted use, distribution, and reproduction in any medium, provided the original work is properly cited.

Dates: Received: 19 March 2020; Revised: 21April 2020; Accepted: 22April 2020

Keywords: Honey, Stingless Bee, Heavy Metals, Atomic Absorption Spectrometry

Stingless bee honey is a desirable bee product which has been consumed for ages in its natural form. (Crane, 2013, Karabagias et al., 2014). It is composed of carbohydrates, amino acids, phenolic compounds, organic acids, vitamins, minerals, lipids and enzymes. These forms the major constituents of the honey. (Manzanares et al., 2014). Honey of stingless bee and Apis are similar in their compositional properties like ash and nitrogen contents (Alvarez et al., 2012). They however defer in terms of moisture content, acidity, viscosity, sucrose and mineral composition (Kek et al., 2016, Vit et al., 2009). Stingless bees for ages on broad spectrum of flowers grow at different types of habitat, hence, producing different honey composition. The botanical source of the nectar, the environmental and climatic conditions as well as the species of the stingless bee mostly determines the physicochemical properties of the stingless bee honey produced. Stingless bee honey can be contaminated with inorganic elements such as heavy metals during the collection of raw materials by the bees or in the honey extraction processes. The content of these heavy metals in an unprocessed honey however depends on several variables such as the botanical origin of the plant visited by the bees as well as the regional and climatic conditions (Clara et al., 2014). In addition to the geographical and botanical origin, the anthropogenic factors near colonies is also a determinant for the presence of high concentrations of metals in bee products (Bogdanov et al., 2007, Silici et al., 2016). Plants accumulate metals in their tissues due to their ability to adapt to various chemical conditions in the environment. For this reason, some plants species are considered as accumulators of metals found in the soil, water and air (Malovolta, 1994). Heavy metals present above the admitted levels by pollution standards are threat to human health (Mbiri et al., 2011). Honey producing bees contact innumerable surfaces during their foraging activities and therefore have been studied as biomonitors of environmental contamination with analysis of honey as a possible indicator of the magnitude of such contamination (Morse and Lisk, 1980). However, due to the paucity of data on this subject in Nigeria, this 
paper examines the honey from stingless bees examined as an indicator to evaluate the level of heavy metals pollution at six sampling locations in and around the University of Ilorin, Kwara State, Nigeria

\section{MATERIAL AND METHODS}

Study site: The collections were carried out in urbanagricultural area of University of Ilorin environ, Ilorin, Kwara State, Nigeria with the following coordinates: Quarters: N08 $27^{\circ} 41.2$, E004 $38^{\prime}$ 32.2; Bolounduro: $\mathrm{N} 08^{\circ} 28$ 32.7, E $004^{\circ} 38^{\prime}$ 37.4; Jalala: N08 29 28.9, E 00438 42.2; Oyun: N 0827 40.1, E 00440 24.6.

Reagent: All reagent used in this study were of analytical grade and doubly distilled water was used in their preparation. The chemicals and reagents needed are; distilled water, conc. Hydrochloric Acid $(\mathrm{HCl})$, conc. Nitric acid $\left(\mathrm{HNO}_{3}\right)$, Sodium Hydroxide $(\mathrm{NaOH})$, Phenolphthalein indicator, ethanol $\left(\mathrm{C}_{2} \mathrm{H}_{5} \mathrm{OH}\right)$, Filter Paper.

Apparatus: The apparatus that was used for this research includes; measuring cylinders, Beakers, glass rod stirrers, Crucibles, PH meter (HANNA instrument, , HI 96107), empty polyethylene bottles, $5 \mathrm{ml}$ density bottles, Hot plate/burner, Analytical weighing balance, oven, muffle Furnace, Burette, Pipette, micro- Pipette, volumetric flask, hot plate or burner, conductivity meter (HANNA instrument USA made in Romania. HI 98129, Atomic Absorption spectrometer, pycnometer, laboratory funnel, Laboratory coat, thermometer, volumetric flask and protective eye glass. The apparatus collected from the department of Industrial Chemistry and Chemistry, University of Ilorin, Ilorin, Nigeria or appropriately sourced from another alternative.

Sampling: The honey samples were collected directly from the colonies in properly identified sterile plastic containers.

Preparation of samples: In the laboratory the honey sample was homogenized by stirring thoroughly at least for three minutes with a glass rod. (IHC, 2002).

Physicochemical Studies: Free Acidity Determination:Acidity was obtained by performing the neutralization of acidic solution of honey. $1 \mathrm{~g}$ of honey was measured and dissolved in $7.5 \mathrm{ml}$ of distilled water. Using $0.01 \mathrm{M}$ sodium hydroxide solution prepared by taken $0.4 \mathrm{~g}$ of $\mathrm{NaOH}$ dissolved in 1liter of distilled water. $1 \%$ of phenolphthalein indicator prepared by adding $1 \mathrm{~g}$ of phenolphthalein powder into $100 \mathrm{ml}$ volumetric flask and adding $40 \mathrm{ml}$ of $95 \%$ ethanol mixed and made up to the mark with $95 \%$ ethanol was used as indicator until a pink colourwas obtained for 10 seconds. The reading of the sodium hydroxide volume required in the titration was recorded and the result expressed in Meq $\mathrm{kg}^{-1}$ using the equation.

$$
\text { Acidity }=\mathrm{V}(\mathrm{NaOH}) \times \mathrm{PA}
$$

Where $\mathrm{V}(\mathrm{NaOH})=$ volume of $\mathrm{NaOH}(\mathrm{ml}), \mathrm{PA}=$ sample weight (g). (Moraes and Teixeira, 1998).

pH Determination: $p \mathrm{H}$ measurement was taken using a $\mathrm{PH}$ meter $.4 \mathrm{~g}$ of honey sample was taken and dissolved in $30 \mathrm{~cm}^{3}$ of distilled water. The mixture homogenized and subjected to reading in a $\mathrm{PH}$ meter according to (AOAC, 2016)

Determination of Density: The density of the honey sample was determined using pycnometry method. The densities of the samples were calculated by the expression;

$$
P=\frac{\left(W_{2}-W_{1}\right) g}{V(\mathrm{~cm})^{3}}
$$

Where; $\mathrm{W}_{1}=$ Mass of pycnometer when empty; $\mathrm{W}_{2}=$ Mass of pycnometer when filled with honey sample; $\mathrm{V}=$ Volume of the pycnometer (Abu-Jdayii et al., 2002).

Determination of Moisture Content: The moisture content was determined using a digital Atago portable refractometer thermostated at $20^{\circ} \mathrm{C}$ and calibrated with distilled water. Few drops of honey were gently placed in the sample plate and then covered. Displayed readings were recorded and the procedure was repeated thrice. (Bogdanov, 2009).

Ash Content Determination: Ash content was determined by weighing $5 \mathrm{~g}$ of honey into a clean, dry crucible. This was preheated with a Bunsen burner to prevent honey foaming. The samples were incinerated in a muffle furnace at high temperature $\left(550^{\circ} \mathrm{C}\right)$ for $5 \mathrm{~h}$. The crucibles were cooled in a dessicator at room temperature and thereafter weighed and recorded accordingly. The ash content was expressed in percentage (\%) using the expression;

$$
\% \mathrm{AC}=\frac{\left(\mathrm{W}_{\mathrm{A}}\right)-\left(\mathrm{W}_{\mathrm{C}}\right)}{\mathrm{W}_{\mathrm{S}}} \times 100
$$

Where; $\mathrm{AC}=$ ash content; $\mathrm{W}_{\mathrm{A}}=$ weight of crucible after ashing; $\mathrm{W}_{\mathrm{C}}=$ weight of empty crucible; $\mathrm{W}_{\mathrm{S}}=$ original weight of sample(AOAC, 2016). 
Determination of Electrical Conductivity: The electrical conductivity was measured using a conductivity meter. $10 \mathrm{~g}$ of honey sample was measured and dissolved in $50 \mathrm{ml}$ of distilled water this was thoroughly mixed to form a solution. The electrical conductivity cell was immersed noting the temperature while the readings were expressed in milli Siemens per centimeter in accordance to (AOAC, 2016).

Determination of Metal Concentration: Sample Digestion: The honey sample was digested using the dry-ashing technique of Uren and Serifoglu (1998). $10 \mathrm{ml}$ of each honey sample was measured using a measuring cylinder into a clean and dried crucible.The honey sample was heated for few minutes in order to dry off any moisture, this is allowed to cool in a desiccator and calcined at $550^{\circ} \mathrm{C}$ in a furnace, the resulting ash was digested through the addition of an aliquot composing of an acid mix of $3 \mathrm{ml}$ concentrated $\mathrm{HNO}_{3}$ (specific gravity 1.18 and $36 \%$ purity) and $1 \mathrm{ml}$ of concentrated $\mathrm{HCl}$ (specific gravity 1.42 and $97 \%$ purity) excess acid was evaporated through drying. The resulting solution is allowed to cool, filtered and transferred to a $100 \mathrm{ml}$ volumetric flask and made up to the volume. A blank digest was also carried out in the same way. The resulting solution was directly measured using Atomic Absorption Spectrometer.

\section{RESULT AND DISCUSSION}

Results of physicochemical parameters of all honey samples analyzed are reported in Table 1 . All the honey samples are acidic. Average $\mathrm{PH}$ for all the studied samples is 4.61 . The $\mathrm{pH}$ values observed in this study are comparatively similar to the work on stingless bee honey $\mathrm{pH}(3.32-4.90)$ as reported by Omafuvbe and Akanbi 2009, Adenekan et al., 2010, while the $\mathrm{pH}$ obtained from Quarter sample is higher though still within the stated $\mathrm{PH}$ of stingless bee honey which ranges from $3.15-6.64$ as reviewed by Nordin, et al., 2018. However, all the samples investigated are within the allowed limit of international honey standards (PH of $3.42-6.10$ ) codex alimentarius, 2018. The low $\mathrm{pH}$ value of honey that is high acidity and possible other factors gives honey its antimicrobial property. However, this acidity may be neutralized in the body by buffering liquid fluids. Average moisture content in this study was $14.25 \%$. As reviewed by Nordin et al., 2018. Moisture content in stingless bee goes from as low as $13.26 \%$ to as high as $45.8 \%$; this variation is due to composition and floral origin from the honey samples.

The average moisture content in this study conforms to be within the limit recommended by the international honey standard (not more than 20\%) codex Alimentations, 2018. In another related work given by Omaya et al., 2014, Eleazu et al., 2013 and Issaro et al., 2013, the moisture content value reported in this study is still within the range given to prevent fermentation caused by micro-organisms and enzymatic factors. In the case of ash content for the honey samples examined in this work, the average value recorded is $1.5 \%$. Ash is a direct measure which represents the inorganic residues after honey carbonization and the variability can be explained in terms of the floral source of the honey (Vit et al., 1998). This of course and other factor make honey from bees a bioindicator. The mean electrical conductivity values of all samples examined is $0.04 \mathrm{mScm}^{-1}$. The electrical conductivity can be described to be in direct relationship to the ash and acid content of honey reflecting the presence of ions and inorganic acids, the higher the ash and the acidity the higher the resulting electrical conductivity (Naman et al., 2005).

The electrical values of the investigated honey samples are within the allowed limit of international standard (not more than $0.8 \mathrm{mScm}^{-1}$. The highest electrical value recorded in this study is similar to the report previously given in the study by Almeida et al., 2013 with stingless bee honey electrical conductivity of $0.10 \mathrm{mscm}^{-1}$.

The free acidity values in this study comply with the set standards by the international honey commission which is free acidity of not more than $50 \mathrm{meqkg}^{-1}$. As reviewed by Nordin et al., 2018, free acidity value for stingless bee honey ranges from $5.9 \mathrm{meqkg}^{-1}$ $592 \mathrm{meqkg}^{-1}$ Stingless bee honey usually features high acidity in comparison to the sting bee honey and this can be reflected in the taste.

Table 1. Physiochemical parameters of Honey samples analyzed form six locations

\begin{tabular}{llllllll}
\hline & \multicolumn{7}{c}{ Sample location } \\
\hline \multirow{2}{*}{ Parameters } & Oyun & $\begin{array}{l}\text { Oyun } \\
\text { A }\end{array}$ & $\begin{array}{l}\text { Bolounduro } \\
\text { B }\end{array}$ & $\begin{array}{l}\text { Bolounduro } \\
\text { B }\end{array}$ & Jalala & \multirow{2}{*}{ Quarters } & Mean \pm SD \\
\hline $\mathrm{pH}$ & 4.30 & 4.38 & 4.54 & 4.64 & 4.71 & 5.08 & $4.61 \pm 0.25$ \\
Free Acidity $\left(\mathrm{meqkg}^{-1}\right)$ & 48.10 & 46.70 & 41.57 & 43.63 & 42.00 & 42.50 & $44.08 \pm 2.46$ \\
Moisture (\%) & 17.05 & 18.17 & 13.33 & 13.77 & 11.77 & 11.46 & $14.25 \pm 2.52$ \\
Density (g/ml) & 1.42 & 1.41 & 1.44 & 1.45 & 1.43 & 1.46 & $1.44 \pm 0.02$ \\
Ash (\%) & $2: 4$ & 2 & 1.3 & 1.8 & 0.6 & 0.8 & $1.48 \pm 0.64$ \\
Electrical cnductivity, Sc/cm) & 0.1 & 0.05 & 0.03 & 0.04 & 0.01 & 0.02 & $0.04 \pm 0.03$ \\
\hline
\end{tabular}

OKEOLA, FO; OLUADE, O; LIADI, NT 
Table 2: Result of heavy metals concentrations in analyzed honey sample in $\mu \mathrm{g} / \mathrm{kg}$.

\begin{tabular}{llllll}
\hline \multicolumn{1}{c}{ Sample } & \multicolumn{1}{c}{$\mathbf{P b}$} & \multicolumn{1}{c}{$\mathbf{C r}$} & \multicolumn{1}{c}{$\mathbf{C d}$} & \multicolumn{1}{c}{$\mathbf{C u}$} & $\mathbf{Z n}$ \\
\hline Oyun A & ND & $1.9 \pm 0.82$ & 0.002 & $2319.33 \pm 0.47$ & $3073.33 \pm 0.47$ \\
Oyun B & ND & $29.67 \pm 0.58$ & $<0.001$ & $592.33 \pm 1.25$ & $3992.33 \pm 0.47$ \\
Bolounduro A & ND & 8.00 & $0.0033 \pm 0.000473$ & $858 \pm 1.41$ & $2209.33 \pm 0.47$ \\
Bolounduro B & ND & 5.00 & 0.010 & $1611.33 \pm 0.47$ & $1755.67 \pm 0.47$ \\
Jalala & ND & $12.33 \pm 5.06$ & 0.001 & $1045.33 \pm 0.47$ & $1899.67 \pm 0.47$ \\
Quarters & 1.00 & $4.33 \pm 0.47$ & $<0.001$ & $983.33 \pm 0.94$ & $2188.67 \pm 0.94$ \\
WHO/FAO MPL & $25 \mu \mathrm{g} / \mathrm{kg}$ & $100 \mathrm{mg} / \mathrm{kg}$ & $0.5 \mathrm{mg} / \mathrm{kg}$ & $300 \mathrm{mg} / \mathrm{kg}$ & $350 \mathrm{mg} / \mathrm{kg}$ \\
\hline \multicolumn{5}{c}{ ND: No detection, MPL: Maximum permissible limit } \\
\hline
\end{tabular}

Heavy Metals Analysis: The proportion of metal in honey depends mostly on what the bees pick for making the honey. Heavy metals among many other materials serve as one of the major pollutants in the environment especially in the soil and water. The heavy metals and other materials find its way through many natural and ecological phenomenon into the systems of bees hence the honey made. Within the limited resource of this research work some metals were studied for this bio indicating purpose. Concentration levels of selected heavy metals are reported in Table 2. The result obtained in this study showed the detection of $\mathrm{Pb}$ only in one sample (Quarters sample), this is likely caused by pollution form vehicular traffic due to proximity of the bee hive to the major busy road of the university. Lead $(\mathrm{Pb})$ is regarded as one of the most widespread toxic metal pollutants. Like cadmium $(\mathrm{Cd})$, they are both nonessential element and are usually detected among the many metals transferred to the body system of bees and their products (Satta et al., 2012; Hladan et al., 2015). $\mathrm{Pb}$ contamination generally correlates with air pollution by industry and exhaust gasses. (kovacik et al., 2016).In this sample concentration determined for $\mathrm{Pb}$ is $1 \mu \mathrm{g} / \mathrm{Kg}$ which is very low to the acceptable levels of $25 \mu \mathrm{g} / \mathrm{Kg}$ jointly proposed by the world Health organization (WHO) and the Food and Agricultural Organization (FAO). Alqorni et al., 2012. In a similar research carried out by Nascimento et al., $2018, \mathrm{~Pb}$ was also detected only in one of the samples. $\mathrm{Pb}$ is considered to have a limited accumulation in plants and not readily bio available to plants (Hladun et al., 2015, Davies et al., 2003) therefore its low concentrations is justified in the raw materials for honey production as the nectar is less exposed to other source of contamination in the environment such as air (Silveira et al., 2013). These may have given a correlation with $\mathrm{Pb}$ concentration below the detection limit in $98 \%$ of the analyzed samples in this study. $\mathrm{Cd}$ is another metallic element whose source is soil passed to plants and nectar (Kovacik et al 2016). Cd in this study presents a very low concentration with the highest value of $0.003 \mu \mathrm{g} / \mathrm{kg}$ detected in Bolounduro A sample while the least value of $0.001 \mu \mathrm{g} / \mathrm{kg}$ was obtained in Jalala sample. There was no Cd detection in Quarters and Oyun B of the honey sample. Highest concentration of $\mathrm{Cd}$ was observed in Bolounduro B, this may have resulted from the use of phosphate fertilizer in the area. Phosphate fertilizer is the main source of $\mathrm{Cd}$ in agricultural soil because it contains $\mathrm{Cd}$ as a contaminant (Williams and David, 1973). Zn was the predominant heavy metal observed in all the studied samples followed by $\mathrm{Cu}$. This can be attributed to their extensive circulation as micro nutrient in the soil to plant system, the natural abundance of $\mathrm{Zn}$ in the soil, intensive use of agrochemicals such as fertilizers and pesticides in neighboring farms close to hive. Oyun B presented the highest value of $\mathrm{Cr}$ having $29.67 \mu \mathrm{g} / \mathrm{kg}$; this may be attributed to its closeness to river due to $\mathrm{Cr}$ deposit in the river which can result from domestic and industrial discharge leading to the contamination of the soil and ground water. The least $\mathrm{Cr}$ concentration of $4.33 \mu \mathrm{g} / \mathrm{kg}$ was reported in Quarters sample.

Conclusion: The present study showed honey contains metals in varying concentration due to different variables associated to the geographical location and origin of the sourced nectar. Detection of these heavy metals which can be threatening to plant and animal lives living within the environment when present above the tolerable limit supports that stingless bees honey is a good bio-indicator of environmental pollution which can be used to constantly monitor contaminants within and around the environment. Although all metals analyzed in this study are below the WHO/FAO permissible limit, application of the appropriate pollution control measure at higher levels after monitoring will help to keep the environment safe andtolerable.

\section{REFERENCES}

Abu-Jdayii B. Al-Majeed G; AI- MalahK; Shahera Z. 2002. Heat effect on rtheology of light and darkcoloured honey. J. Food Eng.51 (1): 33-38.

Adenekan, M; Am us a, N. A; Lawal, A; and Okpeze V. (2016). Physiochemical and microbiological properties of honey samples obtained from Ibadan. J. Microbiol. Antimicrobials. 2(8):100104 
Alqani, A; Owayss A. and Mahmoud; A. (2012). Mineral content and physical properties of local and imported honeys in Saudi Arabia. J. Saudi Chem. Res. 5; 618-625.

Alvarez-Suarez J, Giampieri F, González-Paramás A, (2012).Phenolics from Monofloral Honeys Protect Human Erythrocyte Membranes against Oxidative Damage. Food and Chemical Toxicology 50: 1508-16 and botanical aspects. Bee World, 46: 269-275

Association of Official Analytical Chemists (2016). In; Helrich K. (ed) Official Methods of Analysis, $15^{\text {th }}$ ed; Arlington, VA USA, pp.1025-1026, 10331034.

Ball D. (2007). The chemical composition of Honey $J$. Chem. Edu. 84(10): 1643-1646.

Bogdanov, S; 2009. Harmonised methods of the International Honey Commission. Inter. Honey Commission, pp. 1-61.

Bogdanovs, Jurendic T, Sieber R, Gallmann, P (2008). Honey for nutrition and health. A review. Am J. coll- Nutri, 27: 677-689

Clara N; M. Andrea, G. Giuseppe, N. Francesco, F. Vincenzo (2014). Risk assessment of heavy metals and pesticides in honey from Sicily (Italy). J. Food Res. 3(2), 107-115.

Codex Alimentarius Commission, 2018. Alinorm 41/10: Revised standard for honey, Alinorm, 1, pp. 19-26.

Crane E. The World History of Beekeeping and Honey Hunting: Routledge, 2013.

Eleazu, C; Iroaganachi, M; Okoronkwo, J. (2013). Determination of the physiochemical composition, microbial quality and free radical scavenging activities of same commercially sold honey samples in Abia, Nigeria; the effect of varying color. Inter. J. Biomed. 4 (1):32-41.

Hladun, K. Parker, D. R; Trumble, J. T. (2015). Cadmium, copper and lead accumulation and bio concentration in the vegetative and reproductive organs of Raphanussativus: implications for plant performance and pollination. J. Chem. Ecol. 41:386-395.

International honey commission, 2009. Harmonised methods of the international honey commission.
Pp63, swiss bee research centre, Bern: FAM, Liebefield.

Issaro, N; Weerakul, T; Machena, S; Ornim, P; Phanudulkihi, C; Srijan, T; Laiwahanaphaisal, J; Pattarapanich C. (2013). Stingless bee honey II: Qualitative and Quantitative Studies on Honey Produced By three Stingless Bee Species collected from a mangosteen garden in chantaburi province, Thailand. Thai J. Pharm. Sci. 38 Suppl.

Karabagias I;Badeka A;Kontakos S (2014). Botanical Discrimination of Greek Unifloral Honeys with Physicochemical and Chemometric Analyses. Food Chem. 165: 181-90.

Kek S; Chin N; Tan S (2016). Classification of Honey from Its Bee Origin via Chemical Profiles and Mineral Content. Food Analytical Methods: 1-12.

Kovacik J; Cruz, O. B. and Hedbauny, J (2016) Contents of metals and metabolites in honey originated from the vicinity of industrial town Kosice (eastern slovakia). Environ. Sci. Pollute. Res. 23(5)4531-4540.

Malavolta, E. (1994). Fertilizantes e seuimpactoambiental: micronutrientes e metais pesados: mitos, mistificação e fatos

Manzanares A; García Z;Galdón B; et al; Physicochemical Characteristics of Minor monofloral honeys from Tenerife, Spain

Mbiri A;Onditi A;Oyaro N; Determination of essential and heavy metals in Kenyan micronutrientes e metaispesados, mitos, mistificações e fatos.

Morse R; Lisk, D. (1980). 'Elemental analysis of honeys from several nations', Amer. Bee

Naman M; Faid M; and Adlouni C; (2015). Microbiology and physiochemical properties of Moroccan honey. Int. J. Agric. Bio. 1560(5):773776.

Nordin, A; Sainik, V; Chowdhury, R; Binsaim, A; Idrus, S. (2018). Physicochemical properties of stingless bee honey from around the globe: A comprehensive review. Journal of food composition Analysis. 73:91-102

Omafuvbe, B; Akanbi, O; (2009). Microbiological and physiochemical properties of same commercial Nigeria honey. Afr. J. Microbe Res. 3(12):891-6. 
Omoya, F; Ijabadeniyi, O; Ogonnoh, O; (2014). Physiochemical properties of honey samples from Ondo state, Nigeria, and their bioactivity against spoilage and pathogenic organisms. J. Food Agric. Environ. 12(34):104-107.

Sat ta, A; Verdinelli, M; Ruuu, L; Buffa, F; Sassy, A; Floris, I; (2012). Combination of beehive matrices analysis and anti-biodiversity to study heavy metal pollution impact in a post-mining area (Sardinia, Italy). Environ. Sci. Pollute. Res. 19:3977-3988.

Silici, S; Uluozlu, D; Tuzen, M; Soylak, M; (2016). Vit P; Gutiérrez M; Rodríguez-Malaver A; et al;:Comparación De Mieles ProducidasPor La AbejaYateí (TetragoniscaFiebrigi) En Argentina Y Paraguay. ActabioquímicaClínica Latino Americana. 43: 219-26
Silveira, T; Araujo, D; March, IC; Mareti, A; Olinda, R. (2013). Detection of metals by differential pulse anodic stripping viltamettry (DPASV) in pollen collected from a fragment of the Atlantic forest in piracicaba ISP. Eco toxicology and environmental contamination. 831-36.

Uren. A; Serifoglu Y; (1998). Food Chem. 61, 185

Vit, P; Persano, O; Marano, M; Salas de Mejias, E; (1998). Venezuelan stingless bee honey characterized by multivariate analysis of physicochemical properties apidologic. 29:377389

Williams, O; David, T; (1973). The effect of superphosphate on the cadmium content of soils and plants. Aust. J. Soil Res. 11:43-56.

World health organization (WHO); (1982). Toxicological evaluation of certain food additives. Geneva joint FAO/WHO expert committee of food additives. WHO Food Additives Series number 17. 